Andrieieva, O., Yarmak, O., Kashuba, V., Drozdovska, S., Gineviciene, V., Blagii, O., \& Akimova-Ternovska, M. (2020). Efficiency of a Combined Fitness Program for Improving Physical Condition in Young Women. Teorìa ta Metodika Fizičnogo Vihovannâ, 20(4), 195-204. https://doi.org/10.17309/tmfv.2020.4.01

ISSN 1993-7989 (print). ISSN 1993-7997 (online)

\title{
EFFICIENCY OF A COMBINED FITNESS PROGRAM FOR IMPROVING PHYSICAL CONDITION IN YOUNG WOMEN
}

\author{
Olena Andrieieva ${ }^{1 \mathrm{ABCD}}$, Olena Yarmak ${ }^{2 \mathrm{ABCD}}$, Vitalii Kashuba ${ }^{1 \mathrm{ABCD}}$, Svitlana Drozdovska ${ }^{1 \mathrm{ABCD}}$, \\ Valentina Gineviciene $^{3 \mathrm{ABCD}}$, Oleksandra Blagii ${ }^{1 \mathrm{ABCD}}$, Maria Akimova-Ternovska ${ }^{1 \mathrm{ABCD}}$ \\ ${ }^{1}$ National University of Ukraine on Physical Education and Sport \\ ${ }^{2}$ Bila Tserkva National Agrarian University \\ ${ }^{3}$ Vilnius University \\ Authors' Contribution: A - Study design; B - Data collection; C - Statistical analysis; D - Manuscript Preparation; E - Funds Collection
}

Corresponding Author: Olena Andrieieva, E-mail: olena.andreeva@gmail.com

Accepted for Publication: December 20, 2020

Published: December 25, 2020

DOI: 10.17309/tmfv.2020.4.01

\begin{abstract}
The purpose of this study was to evaluate the effectiveness of a combined exercise program focused on the improvement of young women's physical condition.

Materials and methods. The study involved 62 healthy women (an average age of 29.4 years). More than 50 parameters were assessed (anthropometric indicators, physical capacity and motor abilities, functional status of the cardiorespiratory system, etc.). The structure of physical condition of the women was identified using the factor analysis. The transforming experiment lasted for 14 months.

Results. The physical development indicators had the largest contribution (33.4\%) to the total variance of physical characteristics of the subjects. The second factor related to the functional state and physical performance accounted for $21.6 \%$, the third factor related to coordination abilities accounted for $19.8 \%$, and the fourth factor related to physical fitness accounted for $10.3 \%$ of the total variance. Those four factors explained $85.1 \%$ of the total variance. The 35 indicators, which were selected by the factor analysis and characterized the women's physical condition, were used as criteria for the effectiveness of the proposed exercise program. Participation in the exercise program significantly affected the morphological status of women. Functional indicators of the cardiovascular system improved significantly, including resting heart rate decreased by $16.2 \%(\mathrm{p}<0.05)$. Muscle strength increased by $32.2 \%(\mathrm{p}<0.05)$, speed and strength endurance and speed endurance increased by $31.5 \%$ and $49.1 \%$, respectively $(\mathrm{p}<0.05)$. Exercises targeting coordination abilities lead to improvements in balance ability of women as assessed by the Romberg test (increase by $94.0 \%, \mathrm{p}<0.05$ ) and by the Flamingo test (increase by $65.6 \%, \mathrm{p}<0.05$ ).

Conclusions. The study confirmed the effectiveness of the combined exercise program according to selected criteria. There were significant $(\mathrm{p}<0.05)$ positive changes in physical condition components including physical development, physical fitness, functional state of the cardiorespiratory system and in body balance.

Keywords: program, fitness training, physical condition, young women.
\end{abstract}

\section{Introduction}

Currently, there is a growing interest in new types of physical activity among women, since a sedentary lifestyle has been associated with a variety of health conditions (Andrieieva et al., 2019b; Hakman et al., 2020; Yelizarova et al., 2020). Physical inactivity inevitably results in lower aerobic fitness levels (Baker et al., 2020). Inactivity and poor fitness

(c) Andrieieva, O., Yarmak, O., Kashuba, V., Drozdovska, S., Gineviciene, V., Blagii, O., Akimova-Ternovska, M., 2020. are associated with numerous health issues, including cardiovascular diseases, metabolic disorders (e.g. overweight, obesity, type-2 diabetes), musculoskeletal disorders, pulmonary diseases, cancer, psychological issues, etc. (Heyward \& Gibson, 2014; Kashuba et al., 2020; Truszczynska-Baszak et al., 2015).

Motivating women to an active lifestyle will improve the demographic situation and reduce mortality from heart disease in women (Lamarche et al., 2017; Hakman et al., 2019). This issue becomes especially important, given that it women who make up a significant portion of fitness services 
customers (> $60 \%)$, and among them $38 \%$ are women aged 25 to 34 years (Kashuba et al., 2019). An analysis of the data reported in the literature (Rzepko et al., 2019; Kyslenko et al., 2020) related to the issues of the influence of fitness training on the female body showed that the current stage of the field of recreation and health enhancing physical activity is associated with a rapid expansion of innovative fitness technologies (Kujala et al., 2017; Yarmak et al., 2018; Song et al., 2019).

Over the past decades, new types of both aerobic (Özcan et al., 2018; Barranco-Ruiz \& Villa-González, 2020) and anaerobic (Beqa et al., 2019; Neto et al., 2020) fitness training have appeared and actively grown. There are a huge number of both theoretical and applied studies in this field (Drozdovska et al., 2020; Ginevičienè, 2010; Heyward \& Gibson, 2014). However, there are still untapped methodological reserves in this field. The technology for designing exercise programs is not sufficiently developed, their influence on the body is not fully understood. Therefore, the purpose of the study was to evaluate the efficiency of combined exercise program focused on the improvement of physical condition and well-being of young women.

\section{Materials and Methods}

\section{Participants of the research}

The study included 62 young women (aged 21-34 years); among them, $59.7 \%(n=37)$ were aged under 30 and $40.3 \%$ $(n=25)$ were over 30 with an average age of $29.4 \pm 2.0$ years. All participants gave their written informed consent to participate in this study, which was approved by the local ethics committee and was in accordance with the Helsinki Declaration.

\section{Research organization}

The study was carried out at the Olympic Style Training and Health-Promoting Centre and the Scientific Research Institute of the National University of Ukraine on Physical Education and Sport.
The study included two stages. Stage I was aimed at development of combined exercise program.

A generalized structure of exercise sessions was developed on the basis of the block principle of design. Seven blocks were distinguished on the basis of the focus: warm-up, aerobic, dance, corrective, preventive, relaxation, additional (Table 1). The developed program consisted of 70 min workouts, three times per week. A training experiment lasted for 14 months was conducted to determine the effectiveness of the developed methodology of designing exercise sessions.

Stage II was aimed at evaluating the cumulative effect of exercise sessions based on the unified methodology that included testing for more than 50 indicators (anthropometry, physiological reaction, motor tests, the level of physical condition).

The following anthropometric indicators were measured: height, body weight, circumference measurements of the body by the Martirosov's technique (Martirosov, 1982). These anthropometric measurements were used to calculate the Quetelet index $1(\mathrm{~g} / \mathrm{cm})=$ body weight $(\mathrm{g}) /$ height $(\mathrm{cm})$ Chest excursion $(\mathrm{cm})=$ thoracic circumference at max. inspiration $(\mathrm{cm})$ - thoracic circumference at max. expiration $(\mathrm{cm})$ waist index, WI (arb. un.) = height $(\mathrm{cm}) /$ waist circumference $(\mathrm{cm})$; abdominal index, AI (arb. un.) = height $(\mathrm{cm}) /$ abdominal circumference $(\mathrm{cm})$; hip index, HI (arb. un.) = height (cm) / thigh circumference $(\mathrm{cm})$; shoulder index, SI (arb. un. $)=$ height $(\mathrm{cm}) /$ shoulder circumference $(\mathrm{cm})$. The results were scored according to Table 2 . The technique is described in detail in (Ivaschenko et al., 2008).

To examine the functional state of the cardiovascular system, resting heart rate (HR) was used. The dynamics of heart rate changes was studied to evaluate the intensity of dif-

Table 2. Scale for scoring anthropometric measurements

\begin{tabular}{lccc}
\hline \multicolumn{1}{c}{ Index } & Norm & Slight excess & $\begin{array}{c}\text { Substantial } \\
\text { excess }\end{array}$ \\
\hline Shoulders & $5.6-6.6$ & $4.8-5.5$ & $<4.8$ \\
Waist & $2.0-2.5$ & $1.65-1.9$ & $<1.65$ \\
Abdomen & $1.5-1.7$ & $1.4-1.45$ & $<1.4$ \\
Thigh & $2.6-3.1$ & $2.3-2.5$ & $<2.3$ \\
\hline
\end{tabular}

Table 1. Parameters of the exercise sessions in the combined program

\begin{tabular}{|c|c|c|c|c|c|c|c|c|c|c|}
\hline \multirow[b]{2}{*}{ Block } & \multirow{2}{*}{ 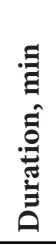 } & \multirow[b]{2}{*}{ 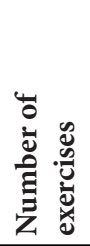 } & \multirow[b]{2}{*}{ 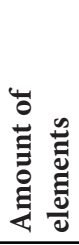 } & \multirow{2}{*}{ 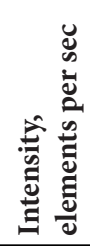 } & \multicolumn{3}{|c|}{$\begin{array}{c}\text { Content of block, } \\
\% \text { of exercises }\end{array}$} & \multicolumn{2}{|c|}{ HR average } & \multirow{2}{*}{$\begin{array}{c}\begin{array}{c}\text { Heart rate } \\
\text { range }\end{array} \\
\text { HRmin } \div \\
\text { HRmax }\end{array}$} \\
\hline & & & & & 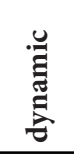 & 岂 & 苞 & bpm & \%HRmax & \\
\hline Warm-up & 8 & 4 & 134 & 0.295 & 60 & 30 & 10 & $114,4 \pm 4$ & 59.3 & $99-130$ \\
\hline Aerobic & 12 & 8 & 467 & 0.78 & 85 & - & 15 & $153 \pm 4$ & 79.6 & $140-172$ \\
\hline Dance & 15 & 16 & 514 & 0.85 & 100 & - & - & $149 \pm 4$ & 77.3 & $140-170$ \\
\hline Corrective & 12 & 10 & 273 & 27.3 & 65.3 & 12.5 & 22.2 & 135 & 70.3 & $10-146$ \\
\hline Preventive & 9 & 5 & 157 & 0.26 & 55 & 45 & - & $125 \pm 2,5$ & 65 & $100-130$ \\
\hline Relaxation & 9 & 4 & 20 & 0.05 & 40 & 60 & - & $92.8 \pm 6$ & 48.3 & 84-98 \\
\hline Additional (balance exercises) & 5 & 4 & 10 & 0.03 & 10 & 90 & - & $102 \pm 4$ & 53 & $90-115$ \\
\hline
\end{tabular}


ferent types of exercises as well as to compare the intensity of different structural blocks of experimental training sessions. During the training sessions, heart rate was measured using the palpation method or with a Polar heart rate monitor and a Polar heart rate analyser.

The systolic and diastolic blood pressure (BPsyst and BPdiast) was measured in the rest. The adaptation capacity of the circulatory system to environmental factors was calculated by the Bayevskiy method:

$\mathrm{AC}=0.011 \times \mathrm{HR}+0.014 \times$ BPsyst $+0.008 \times$ BPdiast + $0.009 \times$ body weight $+0.0014 \times$ age $-0.009 \times$ height -0.27 , where HR is resting heart rate, BPsyst is systolic blood pressure, and BPdiast is diastolic blood pressure.

Rate pressure product (RPP) was calculated by the equation (Ivaschenko et al., 2008):

$\mathrm{RPP}=(\mathrm{HR} \times \mathrm{BPsyst}) / 100$, where $\mathrm{HR}$ is resting heart rate, BPsyst is systolic blood pressure.

The functional state of the respiratory system was assessed using the breath-holding times after inspiration (the Stange test) and after expiration (the Genche test) in seconds. Physical work capacity was evaluated using the Ruffier test by measuring heart rate before and after performing 30 squats in 45 seconds (Ivaschenko et al., 2008).

The following motor abilities were evaluated: flexibility, speed, dynamic strength, speed and speed-strength endurance, balance, and vestibular stability. Physical condition and level of physical preparedness were assessed based on the sum of 11 parameters of the Kontreks-2 scoring system (Table 3) described in detail in (Ivaschenko et al., 2008).

Table 3. Scoring the level of physical condition (Ivaschenko et al., 2008)

\begin{tabular}{lc}
\hline \multicolumn{1}{c}{ Physical condition } & Score, points \\
\hline Low & $<50$ \\
Lower than moderate & $51-90$ \\
Moderate & $90-161$ \\
Higher than moderate & $161-250$ \\
High & $>250$ \\
\hline
\end{tabular}

To examine the biomechanics of stability, the functional state of the body, physical exertion tolerance in terms of ability to maintain a vertical body position, as well as to control the quality of new skills training, stabilographic studies were performed on the Stabilan 01-2 stabilometric platform with biological feedback. Six test tasks were performed: 1) Romberg test; 2) Sharpened Romberg test; 3) Standing on the toes; 4) Standing on the toes with eyes closed; 5) Standing with the head extended backward; 6) Flamingo test (Boloban et al., 1990: Yuriev, 1991).

\section{Statistical analysis}

The statistical analysis of the obtained data was performed using the Statistica ver. 10.0 (Stat Soft, USA) statistical software and the Microsoft Excel 2016 spreadsheets (Microsoft, USA). Only licensed software was used to perform the analysis.

The results of the studies were analysed using the following parameters of descriptive statistics: mean values; sample method; analysis of variance; and factor analysis. The factor analysis was performed by the method of principal com- ponents with varimax rotation. In total, 52 indicators were subjected to the factor analysis including anthropometric measurements, the indicators of physical condition, motor abilities, and functional status of the cardiorespiratory system.

The significance of the difference between the samples was tested at the confidence level of $\mathrm{p}=95 \%$ (significance level of 0.05 ). Some hypotheses were tested at the higher confidence level of $\mathrm{p}=99 \%$ (the significance level of 0.01 ). The Shapiro-Wilk test was used to assess the deviation of the sample distribution from normality. Analysis of variance was used to assess the changes in physical condition parameters of women. For samples with normal distribution, parametric analysis of variance was performed. For samples without normal distribution, the non-parametric Kruskal-Wallis analysis of variance was used (Byshevets et al., 2019).

\section{Results}

Based on the factor analysis, we identified the most important parameters of the physical condition of women to design health-enhancing classes. The factor analysis allowed us to determine the percentage contribution of each factor. Thus, the structure of women's physical condition was determined by a group of four factors: physical development $(33.4 \%)$, functional state of the cardiorespiratory system $(21.6 \%)$, coordination abilities $(19.8 \%)$, and physical preparedness, including speed and speed and strength abilities, agility and flexibility (10.3\%). The total contribution of the four factors to the explained variance was $85.1 \%$, the factor loading matrix is given in table 4 .

The analysis of the factor structure of women's physical condition confirmed that physical development takes a leading place among the factors determining the human physical condition. The first factor, which we associated with physical development, was loaded by the variables that characterise the body measurements: waist circumference $(\mathrm{r}=-0.970$ at $\mathrm{p}<0.01)$; BW $(\mathrm{r}=-0.964, \mathrm{p}<0.01)$; hips circumference $(\mathrm{r}=-0.897, \mathrm{p}<0.01)$; thigh circumference $(\mathrm{r}=-0.893, \mathrm{p}<0.01)$; Quetelet index $1(\mathrm{r}=-0.887, \mathrm{p}<0.01)$; chest circumference $(\mathrm{r}=-0.797, \mathrm{p}<0.01)$; height $(\mathrm{r}=0.782$, $\mathrm{p}<0.01)$; and shoulder circumference $(\mathrm{r}=-0.775, \mathrm{p}<0.01)$.

Furthermore, the first factor was loaded by the variables that characterize the harmony of body shape: waist index $(\mathrm{r}=-0.875, \mathrm{p}<0.01)$; abdominal index $(\mathrm{r}=-0.853, \mathrm{p}<0.01)$; thigh index $(\mathrm{r}=-0.851, \mathrm{p}<0.01)$; and shoulder index $(\mathrm{r}=-0.794, \mathrm{p}<0.01)$. All of them loaded to the first factor, which had the largest contribution $(33.4 \%)$ to the total variance.

The second important factor that determines the structure of the physical condition was loaded by the variables characterizing the function of the cardiorespiratory system and physical work capacity: systolic blood pressure $(\mathrm{r}=0.897$, $\mathrm{p}<0.01)$; resting heart rate $(\mathrm{r}=-0.880, \mathrm{p}<0.01)$; rate pressure product $(\mathrm{r}=-0.874, \mathrm{p}<0.01)$; adaptation capacity $(\mathrm{r}=0.862$, $\mathrm{p}<0.01)$; Ruffier index $(\mathrm{r}=0.832, \mathrm{p}<0.01)$; Genche test $(\mathrm{r}=0.797, \mathrm{p}<0.01)$; diastolic blood pressure $(\mathrm{r}=0.794$, $\mathrm{p}<0.01)$; Stange test $(\mathrm{r}=0.773, \mathrm{p}<0.01)$; and average blood pressure $(\mathrm{r}=0.769, \mathrm{p}<0.01)$. This factor contributed $21.6 \%$ to the total variance.

The third important factor was loaded by the variables that characterize the coordination abilities: sharpened Romberg test $(\mathrm{r}=0.889, \mathrm{p}<0.01)$; Flamingo test $(\mathrm{r}=0.789$, 
Table 4. Factor loading matrix of physical condition variables of women

\begin{tabular}{|c|c|c|c|c|}
\hline Parameters & Factor 1 & Factor 2 & Factor 3 & Factor 4 \\
\hline Height, cm & 0.782 & -0.225 & 0.182 & -0.066 \\
\hline Body weight, kg & -0.964 & -0.481 & 0.079 & 0.026 \\
\hline Quetelet index 1, g/cm & -0.887 & 0.314 & -0.168 & 0.071 \\
\hline Chest circumference, $\mathrm{cm}$ & -0.797 & 0.136 & 0.156 & 0.126 \\
\hline Waist circumference, cm & -0.970 & -0.201 & 0.022 & -0.504 \\
\hline Abdominal circumference, $\mathrm{cm}$ & -0.944 & 0.306 & -0.143 & 0.097 \\
\hline Hips circumference, $\mathrm{cm}$ & -0.897 & 0.219 & 0.043 & 0.639 \\
\hline Thigh circumference, $\mathrm{cm}$ & -0.893 & -0.215 & -0.124 & -0.291 \\
\hline Shoulder circumference, $\mathrm{cm}$ & -0.775 & 0.349 & -0.164 & -0.298 \\
\hline Lower leg circumference, $\mathrm{cm}$ & -0.781 & -0.351 & 0.045 & 0.092 \\
\hline Chest expansion, $\mathrm{cm}$ & 0.790 & 0.281 & 0.171 & 0.298 \\
\hline Waist index, arb. un. & -0.875 & -0.171 & -0.476 & -0.016 \\
\hline Abdominal index, arb. un. & -0.853 & -0.259 & -0.188 & -0.609 \\
\hline Thigh index, arb. un. & -0.851 & 0.134 & -0.032 & -0.208 \\
\hline Shoulder index, arb. un. & -0.794 & -0.109 & -0.006 & -0.028 \\
\hline Resting HR, bpm & -0.353 & -0.880 & -0.004 & 0.003 \\
\hline BPsyst, mm Hg & -0.402 & 0.897 & -0.146 & 0.069 \\
\hline BPdiast, mm Hg & -0.229 & 0.794 & 0.011 & 0.022 \\
\hline $\mathrm{BPav}, \mathrm{mm} \mathrm{Hg}$ & 0.388 & 0.769 & 0.123 & 0.070 \\
\hline Rate pressure product, arb. un. & -0.227 & -0.874 & -0.083 & -0.233 \\
\hline Stange test, $\mathrm{s}$ & 0.584 & 0.773 & 0.027 & 0.104 \\
\hline Genche test, s & 0.276 & 0.797 & 0.637 & 0.244 \\
\hline Ruffier index, arb. un. & 0.256 & 0.832 & 0.332 & 0.320 \\
\hline Adaptation capacity, arb. un. & 0.362 & 0.862 & 0.262 & 0.047 \\
\hline $\begin{array}{l}\text { Flexibility test: bending forward at the waist with the knees locked in } \\
\text { the straight position with the zero mark at the level of the feet, } \mathrm{cm}\end{array}$ & 0.211 & 0.065 & 0.111 & 0.811 \\
\hline Reaction time ruler test, $\mathrm{cm}$ & -0.335 & -0.378 & -0.080 & -0.780 \\
\hline Vertical jump test, $\mathrm{cm}$ & 0.355 & 0.310 & 0.023 & 0.723 \\
\hline $\begin{array}{l}\text { Straight leg lift in a supine position test, max number of lifts performed } \\
\text { during } 20 \mathrm{~s}\end{array}$ & 0.187 & 0.234 & 0.189 & 0.789 \\
\hline Push-up test, number of push-ups performed during $30 \mathrm{~s}$ & 0.164 & 0.212 & 0.031 & 0.731 \\
\hline Romberg test, $s$ & 0.399 & 0.424 & 0.743 & 0.043 \\
\hline Sharpened Romberg test, s & 0.162 & 0.317 & 0.889 & 0.189 \\
\hline Standing on the toes, $s$ & 0.186 & 0.270 & 0.722 & 0.022 \\
\hline Standing on the toes with eyes closed, $s$ & 0.281 & 0.337 & 0.728 & 0.028 \\
\hline Standing with the head extended backward, s & 0.317 & 0.132 & 0.704 & 0.104 \\
\hline Flamingo test, $\mathrm{s}$ & 0.625 & 0.314 & 0.789 & 0.189 \\
\hline Total variance & 6.502 & 5.617 & 5.405 & 2.824 \\
\hline $\mathrm{D}(\mathrm{F}), \%$ & 33.4 & 21.6 & 19.8 & 10.3 \\
\hline
\end{tabular}

$\mathrm{p}<0.01)$; Romberg test $(\mathrm{r}=0.743, \mathrm{p}<0.01)$; standing on the toes with eyes closed $(r=0.728, p<0.01)$; standing on the toes $(\mathrm{r}=0.722, \mathrm{p}<0.01)$; and standing with the head extended backward $(\mathrm{r}=0.704, \mathrm{p}<0.01)$. This factor contributed $19.8 \%$ to the total variance.

The fourth important factor that determines the structure of the physical condition of women was loaded by indicators of the speed, and speed and strength abilities, and flexibility: flexibility test, bending forward at the waist with the knees locked in the straight position with the zero mark at the level of the feet $(r=0.811, p<0.01)$; reaction time ruler test $(r=-0.780$, $\mathrm{p}<0.01)$; straight leg lift in a supine position test, max number of lifts performed during $20 \mathrm{~s}(\mathrm{r}=0.789, \mathrm{p}<0.01)$; push-up test, number of push-ups performed during $30 \mathrm{~s}(\mathrm{r}=0.731$, $\mathrm{p}<0.01)$; and vertical jump test $(\mathrm{r}=0.723, \mathrm{p}<0.01)$.
The analysis of the factor structure of the physical condition of women made it possible to identify 35 parameters (Table 5), which we later used as criteria for the effectiveness of the proposed exercise program.

The circumference measures of the chest and limbs decreased as a result of a decrease in fat mass in women, which was not associated with a decrease in the muscle mass as evidenced by an improvement in the strength indicators of the participants.

The study indicated a high effectiveness of the developed technology of fitness training. The program designed using the unified approach can improve body shape and has a positive effect on the morphological status of women. The decrease in body weight was $5.6 \%(\mathrm{p}<0.05)$. The body circumference measures decreased as follows: the height- 
Table 5. The changes in the morphological and functional status of young women $(n=62)$

\begin{tabular}{|c|c|c|c|c|c|}
\hline \multirow[t]{2}{*}{ Parameters } & \multicolumn{2}{|c|}{$\begin{array}{l}\text { Before the } \\
\text { experiment }\end{array}$} & \multicolumn{2}{|c|}{$\begin{array}{c}\text { After the } \\
\text { experiment }\end{array}$} & \multirow[t]{2}{*}{$\mathbf{p}$} \\
\hline & $\mathbf{X}$ & s & $\mathbf{X}$ & $\mathbf{s}$ & \\
\hline Height, cm & 166.7 & 2.43 & 166.7 & 2.43 & $>0.01$ \\
\hline Body weight, kg & 62.2 & 3.17 & 58.7 & 3.66 & $<0.05$ \\
\hline Quetelet index 1, g/cm & 376.4 & 21.33 & 338.5 & 12.43 & $<0.05$ \\
\hline Chest circumference, $\mathrm{cm}$ & 95.3 & 2.49 & 88.7 & 2.19 & $<0.05$ \\
\hline Waist circumference, $\mathrm{cm}$ & 75.3 & 0.17 & 67.1 & 0.21 & $<0.05$ \\
\hline Abdominal circumference, $\mathrm{cm}$ & 94.3 & 4.85 & 86.5 & 3.97 & $<0.05$ \\
\hline Hips circumference, $\mathrm{cm}$ & 99.1 & 3.72 & 92.4 & 3.76 & $<0.05$ \\
\hline Thigh circumference, $\mathrm{cm}$ & 57.6 & 2.87 & 53.5 & 0.22 & $<0.05$ \\
\hline Shoulder circumference, $\mathrm{cm}$ & 28.1 & 1.46 & 26.9 & 1.05 & $>0.05$ \\
\hline Lower leg circumference, $\mathrm{cm}$ & 37.1 & 1.25 & 34.8 & 2.11 & $<0.05$ \\
\hline Chest expansion, $\mathrm{cm}$ & 5.2 & 1.33 & 7.8 & 1.16 & $<0.05$ \\
\hline Waist index, arb. un. & 2.3 & 0.16 & 2.7 & 0.18 & $<0.05$ \\
\hline Abdominal index, arb. un. & 1.8 & 0.04 & 1.9 & 0.04 & $<0.05$ \\
\hline Thigh index, arb. un. & 2.8 & 0.14 & 3.0 & 0.16 & $<0.05$ \\
\hline Shoulder index, arb. un. & 6.3 & 0.22 & 6.2 & 0.23 & $>0.01$ \\
\hline Resting HR, bpm & 75.4 & 4.98 & 63.2 & 2.34 & $<0.05$ \\
\hline BPsyst, mm Hg & 115.7 & 6.24 & 105.1 & 4.38 & $<0.05$ \\
\hline BPdiast, mm Hg & 75.0 & 3.27 & 67.0 & 5.41 & $<0.05$ \\
\hline $\mathrm{BPav}, \mathrm{mm} \mathrm{Hg}$ & 86.3 & 5.42 & 78.7 & 4.76 & $<0.05$ \\
\hline Rate pressure product, arb. un. & 83.6 & 6.34 & 65.4 & 4.27 & $<0.05$ \\
\hline Stange test, $\mathrm{s}$ & 32.8 & 7.39 & 50.4 & 5.88 & $<0.05$ \\
\hline Genche test, s & 19.1 & 4.31 & 27.5 & 2.72 & $<0.05$ \\
\hline Ruffier index, arb. un. & 10.7 & 1.85 & 8.5 & 1.04 & $<0.05$ \\
\hline Adaptation capacity, arb. un. & 3.4 & 0.04 & 2.6 & 0.03 & $<0.05$ \\
\hline
\end{tabular}

to-waist ratio by $8.3 \%(\mathrm{p}<0.05)$, height-to-abdomen ratio by $10.9 \%(\mathrm{p}<0.05)$, and height-to-thigh ratio by $8.3 \%$ $(\mathrm{p}<0.05)$. Chest expansion after the completion of the program increased by $50.0 \%(\mathrm{p}<0.05)$.

The functional status was also improved that is indicated by a decrease in the resting heart rate by $16.2 \%(\mathrm{p}<0.05)$, a decrease in blood pressure by $9.2 \%-10.7 \%(\mathrm{p}<0.05)$, an increase in breath-holding times by $44.0 \%-53.7 \%$ $(\mathrm{p}<0.05)$, and decrease in adaptive capacity by $23.5 \%(\mathrm{p}<$ 0.05 ) that suggest reduced risk of cardiovascular disease.

Physical work capacity indicators increased significantly: response of the cardiovascular system to the dynamic exercise load improved by $20.6 \%$ ( $\mathrm{p}<0.05)$. Significant positive changes were observed in the motor development indicators (Table 6). Strength and weight training exercises resulted in an increase in strength by $32,2 \%(\mathrm{p}<0.05)$, in speed by $27.2 \%$, in speed-strength endurance and strength endurance by $31.5 \%$ and $49.1 \%$, respectively $(\mathrm{p}<0.05)$.

The stretching exercises contributed to improved functional condition of the muscles and their nutrition, as well as to increased flexibility (by $63.7 \%, \mathrm{p}<0.05$ ).

The assessment with the Kontreks- 2 scoring system (Table 7) showed that the individual level of physical condition in the most of the women at the beginning of the experiment was below average. At the end of the study, we observed an improvement in the level of physical condition of women by an average of $32.6 \%(\mathrm{p}<0.05)$.

The initial and final levels of balance performance were evaluated with six motor tests using stabilography in the group of women who participated in the exercise program
Table 6. Changes in motor development of young women $(\mathrm{n}=62)$

\begin{tabular}{|c|c|c|c|}
\hline \multirow[t]{2}{*}{ Test, motor task } & $\begin{array}{c}\text { Before } \\
\text { experiment }\end{array}$ & $\begin{array}{c}\text { After } \\
\text { experiment }\end{array}$ & \multirow{2}{*}{$\mathbf{p}$} \\
\hline & $\mathrm{X} \pm \mathrm{s}$ & $\mathrm{X} \pm \mathrm{s}$ & \\
\hline $\begin{array}{l}\text { Flexibility test: bending } \\
\text { forward at the waist with } \\
\text { the knees locked in the } \\
\text { straight position with the } \\
\text { zero mark at the level of the } \\
\text { feet, cm }\end{array}$ & $10.2 \pm 2.19$ & $16.7 \pm 2.48$ & $<0.05$ \\
\hline Reaction time ruler test, $\mathrm{cm}$ & $24.6 \pm 3.44$ & $17.9 \pm 1.65$ & $<0.05$ \\
\hline Vertical jump test, $\mathrm{cm}$ & $25.4 \pm 2.87$ & $33.4 \pm 4.15$ & $<0.05$ \\
\hline $\begin{array}{l}\text { Straight leg lift in a supine } \\
\text { position test, max number } \\
\text { of lifts performed during } \\
20 \mathrm{~s}\end{array}$ & $10.8 \pm 1.76$ & $16.1 \pm 1.41$ & $<0.05$ \\
\hline $\begin{array}{l}\text { Push-up test, number of } \\
\text { push-ups performed during } \\
30 \mathrm{~s}\end{array}$ & $14.3 \pm 5.36$ & $18.9 \pm 3.22$ & $<0.05$ \\
\hline $\begin{array}{l}\text { Kontreks-2 total score, } \\
\text { points }\end{array}$ & $156.4 \pm 28$ & $207.4 \pm 18$ & $<0.05$ \\
\hline
\end{tabular}

Table 7. Distribution of the women by physical condition at the beginning and at the end of the pedagogical experiment, $\%(\mathrm{n}=62)$

\begin{tabular}{lccccc}
\hline \multicolumn{1}{c}{$\begin{array}{c}\text { Time of } \\
\text { assessment }\end{array}$} & High & $\begin{array}{c}\text { Higher } \\
\text { than } \\
\text { moderate }\end{array}$ & Moderate & $\begin{array}{c}\text { Lower } \\
\text { than } \\
\text { moderate }\end{array}$ & Low \\
\hline $\begin{array}{l}\text { At the beginning } \\
\text { of the study }\end{array}$ & 0.0 & 9.7 & 19.4 & 56.5 & 14.4 \\
$\begin{array}{l}\text { At the end of the } \\
\text { study }\end{array}$ & 6.5 & 27.4 & 53.2 & 12.9 & 0.0 \\
\hline
\end{tabular}

for 2 years (Table 8). The use of general exercises with higher coordination requirements contributed to significant improvements in balance control ranged from $94.0 \%$ to $65.6 \%(\mathrm{p}<0.05)$.

We recorded a decrease in the number of balance losses and an improvement in balance control when performing complicated motor tasks.

At the end of the training experiment, there was a significant $(p<0.05)$ decrease in the maximum amplitude of trunk sway, resulted in the corresponding positive changes in the ground reaction forces. Balance control has improved in the stance with the head extended backward that indicates an improvement in spatial orientation. Improvements in the Romberg test were the most substantial. There was a significant $(\mathrm{p}<0.05)$ decrease in the average and maximum range of sway in the sagittal and frontal planes when performing the test of standing on the toes with eyes closed. However, it should be noted that inconsistent performance of balance exercises in training sessions does not bring the desired effect. It is necessary to perform balance exercises regularly and to monitor the changes in balance control using special tests.

\section{Discussion}

The feasibility of using factor analysis of physical indicators to determine the relationships among variables and to re- 
Table 8. Changes in postural stability of women, $n=62$

\begin{tabular}{|c|c|c|c|c|c|c|c|}
\hline \multirow{3}{*}{ No. } & \multirow{3}{*}{$\begin{array}{c}\text { Motor } \\
\text { tests }\end{array}$} & \multicolumn{2}{|c|}{$\begin{array}{l}\text { Average amplitude of trunk sway } \\
\qquad X \pm s\end{array}$} & \multicolumn{2}{|c|}{$\begin{array}{c}\text { Maximum amplitude of trunk } \\
\text { sway } \\
X \pm s\end{array}$} & \multicolumn{2}{|c|}{$\begin{array}{l}\text { Frequency of sway } \\
\qquad X \pm s\end{array}$} \\
\hline & & \multicolumn{6}{|c|}{ Planes of motion } \\
\hline & & $\mathrm{S}$ & $\mathrm{F}$ & $S$ & $\mathbf{F}$ & $S$ & $\mathrm{~F}$ \\
\hline \multirow{4}{*}{1} & \multicolumn{7}{|c|}{ Romberg test } \\
\hline & $\mathrm{BE}$ & $5.7 \pm 0,54$ & $6.7 \pm 0.15$ & $17.2 \pm 4.26$ & $20.3 \pm 4.18$ & $7.4 \pm 0.58$ & $7.6 \pm 0.75$ \\
\hline & $\mathrm{AE}$ & $3.2 \pm 0.18$ & $4.1 \pm 0.09$ & $9.1 \pm 1.28$ & $11.2 \pm 2.04$ & $4.2 \pm 0.23$ & $4.5 \pm 0.21$ \\
\hline & $\mathrm{p}$ & $<0.05$ & $<0.05$ & $<0.05$ & $<0.05$ & $<0.05$ & $<0.05$ \\
\hline \multirow{4}{*}{2} & \multicolumn{7}{|c|}{ Sharpened Romberg test } \\
\hline & $\mathrm{BE}$ & $6.8 \pm 0.45$ & $6.5 \pm 0.27$ & $17.3 \pm 0.51$ & $23.4 \pm 0.42$ & $3.9 \pm 0.27$ & $4.3 \pm 0.26$ \\
\hline & $\mathrm{AE}$ & $4.2 \pm 0.37$ & $4.3 \pm 0.13$ & $11.5 \pm 0.38$ & $15.2 \pm 0.21$ & $2.1 \pm 0.12$ & $2.4 \pm 0.13$ \\
\hline & $\mathrm{p}$ & $<0.05$ & $<0.05$ & $<0.05$ & $<0.05$ & $<0.05$ & $<0.05$ \\
\hline \multirow{4}{*}{3} & \multicolumn{7}{|c|}{ Standing on the toes } \\
\hline & $\mathrm{BE}$ & $14.9 \pm 1.47$ & $13.7 \pm 0.87$ & $18.5 \pm 2.45$ & $17.4 \pm 3.43$ & $4.6 \pm 0.35$ & $3.3 \pm 0.44$ \\
\hline & $\mathrm{AE}$ & $10.1 \pm 0.85$ & $9.1 \pm 0.38$ & $13.1 \pm 2.04$ & $12.2 \pm 3.07$ & $2.1 \pm 0.21$ & $2.9 \pm 0.41$ \\
\hline & $\mathrm{p}$ & $<0.05$ & $<0.05$ & $<0.05$ & $<0.05$ & $<0.05$ & $>0.05$ \\
\hline \multirow{4}{*}{4} & \multicolumn{7}{|c|}{ Standing on the toes with eyes closed } \\
\hline & $\mathrm{BE}$ & $28.4 \pm 2.43$ & $24.1 \pm 2.33$ & $41.3 \pm 3.74$ & $29.7 \pm 2.19$ & $2.8 \pm 0.13$ & $2.4 \pm 0.29$ \\
\hline & $\mathrm{AE}$ & $20.2 \pm 1.76$ & $16.2 \pm 1.42$ & $28.1 \pm 1.96$ & $20.1 \pm 1.27$ & $2.5 \pm 0.09$ & $2.2 \pm 0.07$ \\
\hline & $\mathrm{p}$ & $<0.05$ & $<0.05$ & $<0.05$ & $<0.05$ & $>0.05$ & $>0.05$ \\
\hline \multirow{4}{*}{5} & \multicolumn{7}{|c|}{ Standing with the head extended backward } \\
\hline & $\mathrm{BE}$ & $15.8 \pm 2.43$ & $12.0 \pm 2.63$ & $21.3 \pm 2.37$ & $18.7 \pm 2.63$ & $2.8 \pm 0.43$ & $2.4 \pm 0.31$ \\
\hline & $\mathrm{AE}$ & $10.7 \pm 1.51$ & $10.9 \pm 1.28$ & $15.2 \pm 1.64$ & $12.4 \pm 1.42$ & $2.4 \pm 0.22$ & $2.2 \pm 0.12$ \\
\hline & $\mathrm{p}$ & $<0.05$ & $>0.05$ & $<0.05$ & $<0.05$ & $>0.05$ & $>0.05$ \\
\hline \multirow{4}{*}{6} & \multicolumn{7}{|c|}{ Flamingo test } \\
\hline & $\mathrm{BE}$ & $22.7 \pm 3.14$ & $25.4 \pm 3.42$ & $26.3 \pm 3.53$ & $29.9 \pm 3.34$ & $4.7 \pm 0.81$ & $5.7 \pm 0.62$ \\
\hline & $\mathrm{AE}$ & $16.2 \pm 2.17$ & $18.1 \pm 1.25$ & $20.2 \pm 1.31$ & $22.4 \pm 1.73$ & $4.1 \pm 0.52$ & $5.2 \pm 0.41$ \\
\hline & $\mathrm{p}$ & $<0.05$ & $<0.05$ & $<0.05$ & $<0.05$ & $>0.05$ & $>0.05$ \\
\hline
\end{tabular}

Note: $\mathrm{BE}$ - before the experiment; AE - after the experiment; $\mathrm{S}$ - sagittal plane; F - frontal plane

duce the number of variables needed to describe the data has been confirmed in a number of studies (Galan et al., 2019a, Yarmak et al., 2019). The analysis of the factor structure of women's physical condition confirmed that physical development play an important role among the factors determining the physical condition (Goncharova et al, 2020, Gurieieva 2014). Our data are consistent with the reported data (Peterman et al., 2019) that showed the importance of the indicators of the functional state of the cardiorespiratory system, coordination abilities, and physical fitness. The relationships between indicators of physical development, functional status, and coordination abilities have been confirmed (Güler \& Yüksek \& Göksu, 2020; Podrigalo, et al., 2019). We used the data of factor analysis to select the most informative criteria for the effectiveness of the proposed health-enhancing exercise program. The similar approaches were taken in the studies of Goncharova et al. (2020) and Yarmak et al. (2018).

To improve the physical condition of young women, a wide range of health-enhancing exercises have been proposed (Chukhlantseva, 2020, Kashuba et al., 2020). For example, a positive effect was achieved with the use of aerobic (Barranco-Ruiz, 2020) and strength exercises (Beqa et al., 2019, Zhygalova, 2003) as well as of "Smart Body" programs
(Kashuba et al., 2020, Özcan et al., 2018). According to Ivaschenko et al. (2008), the predominance of aerobic exercise in the workouts results in a significant increase in overall endurance and some indicators of the functional state of the cardiovascular system, but significantly less improvement in other fitness components. In contrast, performing a program with a predominance of strength exercises and "Smart Body" programs was accompanied with a significant improvement in a number of indicators of development of muscle groups and joint mobility. According to Ivaschenko et al. (2008), the most effective is a combined approach. The effectiveness of using combined exercise programs for people of various ages has been demonstrated in the studies of Galan et al. (2019b) and Zhygalova (2003). Ivaschenko et al. (2008) found that the most optimal training mode is a mixed physical activity that combines mainly aerobic exercises with anaerobic ones, which are performed in the form of short repetitions. Studies have shown that this training mode provides a significant increase in physical and functional fitness (Andrieieva et al., 2019a, Kozhokar et al., 2019).

The importance of monitoring balance control in women of different ages is pointed out by Olchowik et al. (2020). Tavares et al. (2019) substantiated the use of exercise with 
a predominant focus on improving balance ability in exercise programs for middle-aged women. Coordination of the vertical position of the body in the standing position is an indicator of the functional state and health of an individual (Boloban et al., 1999). Direct relationships among physical development, physical fitness, and the function of the vestibular sensory system have been established (TruszczynskaBasza et al., 2015).

Summarizing the available approaches for designing exercise programs for young women, we have proposed a combined approach to program design. The designed program included a balanced ratio of aerobic and strength training, stretching, and coordination exercises. The effectiveness of the program was evaluated according to the indicators identified in the factor analysis. We observed an improvement in the physical condition of young women who participated in the program. Our results support and corroborate the results of previous studies on the effectiveness of combined programs for improving coordination skills (Truszczynska-Basza et al., 2015), the functional state of the cardiorespiratory system (Baker et al., 2020), physical development (Vysotskaya et al., 2020; Goncharova et al., 2020), and physical fitness (Galan et al., 2019b). The findings of our study are consistent with the data of Yarmak et al. (2019) about the beneficial effects of exercise training.

\section{Conclusions}

Evaluation of the effectiveness of the combined fitness program revealed noticeable positive long-term effects on the level of physical condition, morphological status, health status, and general well-being of young women. The results of the study can be useful for fitness professionals when choosing and developing new health-enhancing exercise programs for young women.

The studies showed positive changes in the physical condition of young women who participated in the program.

In conclusion, we note that designing of a specially organized physical training aimed at improving the health of various population groups, in particular of women, is associated with the need to use a variety of means and a wide range of methods. This is dictated, on the one hand, by the interests of people of different ages and levels of fitness and physical condition, and, on the other hand, by the specificity of the impact of physical exercises on the body.

\section{Conflicts of interest}

The authors declare that there are no conflicts of interest.

\section{References}

Andrieieva, O., Hakman, A., Kashuba, V., Vasylenko, M., Patsaliuk, K., Koshura, A., \& Istyniuk, I. (2019a). Effects of physical activity on aging processes in elderly persons. Journal of Physical Education and Sport, 20(3), 1308-1314. https://doi.org/10.7752/jpes.2019.s4190

Andrieieva, O., Kashuba, V., Carp, I., Blystiv, T., Palchuk, M., Kovalova, N., \& Khrypko, I. (2019b). Assessment of emotional state and mental activity of 15-16 year-old boys and girls who had a low level of physical activity. Journal of Physical Education and Sport, 19(3), 1022-1029. https://doi.org/10.7752/jpes.2019.s3147

Baker, S. E., Limberg, J. K., Scruggs, Z. M., Curry, T. B., Nicholson, W. T., Barnes, J. N., \& Joyner, M. J. (2020). Greater influence of aerobic fitness on autonomic support of blood pressure in young women than in older women. Hypertension, 75(6), 1497-1504. https://doi.org/10.1161/HYPERTENSIONAHA.119.14042

Barranco-Ruiz, Y., \& Villa-González, E. (2020). Health-related physical fitness benefits in sedentary women employees after an exercise intervention with Zumba Fitness ${ }^{\oplus}$. International Journal of Environmental Research and Public Health, 17(8), 2632. https://doi.org/10.3390/ijerph17082632

Barranco-Ruiz, Y., Paz-Viteri, S., \& Villa-González, E. (2020). Dance fitness classes improve the health-related quality of life in sedentary women. International Journal of Environmental Research and Public Health, 17(11), 3771. https://doi.org/10.3390/ijerph17113771

Beqa, G., Elezi, A., \& Elezi, G. (2019). The impact of powerful programed exercises on fitness, on body composition. Journal of Education, Health and Sport, 9(8), 950-961. https://doi.org/10.5281/zenodo.3408563

Boloban, V. N., Silchenko, B. G., \& Biriuk, E. V. (1990). The technique of stabilography in studies of the stability of a body and a system of bodies when performing gymnastic, acrobatic exercises: Method. recommendations. Kiev: KGIFK.

Byshevets, N., Denysova, L., Shynkaruk, O., Serhiyenko, K., Usychenko, V., Stepanenko, O., \& Iryna, S. (2019). Using the methods of mathematical statistics in sports and educational research of masters in physical education and sport. Journal of Physical Education and Sport, 19(6), 10301034. https://doi.org/10.7752/jpes.2019.s6311

Chukhlantseva, N. (2019). Effectiveness of an indoor cycling program in improving the physical condition of young women. Polish Journal of Sport and Tourism, (26), 14-19. https://doi.org/10.2478/pjst-2019-0015

Drozdovska, S., Andrieieva, O., Yarmak, O., \& Blagii, O. (2020). Personalization of health-promoting fitness programs for young women based on genetic factors. Journal of Physical Education and Sport, 20(1), 331-337. https://doi.org/10.7752/jpes.2020.s1046

Ivaschenko, L. Ya., Blagii, A. L., \& Usachev, Yu. A. (2008). Programming health-enhancing exercise sessions [Programmirovanie zaniatiy ozdorovitel'nym fitnesom]. Kyiv: Naukovyi svit.

Galan, Y., Andrieieva, O., \& Yarmak, O. (2019a). The relationship between the indicators of morpho-functional state, physical development, physical fitness and health level of girls aged 12-13 years. Journal of Physical Education and Sport, 19(2), 1158-1163. https://doi.org/10.7752/jpes.2019.02168

Galan, Y., Andrieieva, O., Yarmak, O., \& Shestobuz, O. (2019b). Programming of physical education and health-improving classes for the girls aged 12-13 years. Journal of Human Sport and Exercise, 15(3). https://doi.org/10.14198/jhse.2020.153.05 
Ginevičienė, V., Pranckevičienė, E., Milašius, K., \& Kučinskas, V. (2010). Relating fitness phenotypes to genotypes in Lithuanian elite athletes. Acta Medica Lituanica, 17(1-2), 1-10.

Goncharova, N., Kashuba, V., Tkachova, A., Khabinets, T., Kostiuchenko, O., \& Pymonenko, M. (2020). Correction of postural disorders of mature age women in the process of aqua fitness taking into account the body type. Teoriâ ta Metodika Fizičnogo Vihovannâ, 20(3), 127-136. https://doi.org/10.17309/tmfv.2020.3.01

Güler, M. Ş., Yüksek, S., \& Göksu, Ö. (2020). Investigation of the relationship between body mass index and physical fitness in older women. International journal of Science Culture and Sport, 8(1), 1-10.

https://doi.org/10.14486/IntJSCS.2020.591

Gurieieva, A.M., \& Klopov, R.V. (2014). Factor structure of physical state of female students of higher education institution. Pedagogics, psychology, medical-biological problems of physical training and sports, 7, 7-11. https://doi.org/10.6084/m9.figshare.1015378

Hakman, A., Andrieieva, O., Kashuba, V., Nakonechnyi, I., Cherednichenko, S., Khrypko, I., Tomilina, Y., Filak, F., \& Moldovan A. (2020) Characteristics of biogeometric profile of posture and quality of life of students during the process of physical education. Journal of Physical Education and Sport, 20(1), 79-85. https://doi.org/10.7752/jpes.2020.01010

Hakman, A., Andrieieva, O., Kashuba, V., Omelchenko, T., Carp, I., Danylchenko, V., \& Levinskaia K. (2019) Technology of planning and management of leisure activities for working elderly people with a low level of physical activity. Journal of Physical Education and Sport, 19(6), 2159-2166. https://doi.org/10.7752/jpes.2019.s6324

Heyward, V.H. \& Gibson, A.L. (2014) Advanced fitness assessment and exercise prescription. 7th edition, Human Kinetics.

Kashuba, V., Andrieieva, O., Goncharova, N., Kyrychenko, V., Karp, I., Lopatskyi, S., \& Kolos, M. (2019). Physical activity for prevention and correction of postural abnormalities in young women. Journal of Physical Education and Sport. Supplement issue, 19(2), 500-506. https://doi.org/10.7752/jpes.2019.s2073

Kashuba, V., Tomilina, Y., Byshevets, N., Khrypko, I., Stepanenko, O., Grygus, I., Smoleńska, O., \& Savliuk, S. (2020). Impact of Pilates on the intensity of pain in the spine of women of the first mature age. Teoriâ ta Metodika Fizičnogo Vihovannâ, 20(1), 12-17. https://doi.org/10.17309/tmfv.2020.1.02

Kozhokar, M., Vaskan, I., Palagniuk, T., Zavgorodnia, T., Strazhnikova, I., Kyselytsia, O., Balatska, L., \& Yarmak, O. (2019). The complex effects of health-improving fitness on the physical condition of students. Journal of Physical Education and Sport, 19(6), 2133-2138. https://doi.org/10.7752/jpes.2019.s6320

Kujala, U., Pietilä, J., Myllymäki, T., Mutikainen, S., Föhr, T., Korhonen, I., \& Helander, E. (2017). Physical activity: Absolute intensity versus relative-to-fitness-level volumes. Medicine \& Science in Sports \& Exercise, 49(3), 474-481

Lamarche, D.T., Notley, S.R., Poirier, M.P., \& Kenny, G.P. (2017). Fitness-related differences in the rate of whole- body total heat loss in exercising young healthy women are heat-load dependent. Experimental Physiology, 103(3), 312-317. https://doi.org/10.1113/EP086752

Martirosov, E. G. (1982). Methods of the study in sports anthropology. Moscow: Fizkultura i sport.

Neto, A. R., de Walsh, I. A. P., \& Bertoncello, D. (2020). Benefits of extreme fitness programs for women. REFACS, 8(2), 274-281. https://doi.org/10.18554/refacs.v8i2.4336

Özcan, R., Irez, G. B., Saygin, Ö., \& Ceylan, H. İ. (2018). Aqua-Pilates exercises improves some physical fitness parameters of healthy young women. Journal of Physical Education \& Sports Science, 12(3), 160-175.

Olchowik, G., Czwalik, A., \& Kowalczyk, B. (2020). The Changes in Postural Stability of Women in Early Old Age. The Journal of Nutrition, Health \& Aging, 24(7), 739-744. https://doi.org/10.1007/s12603-020-1399-Z

Peterman, J., Arena, R., Myers, J., Marzolini, S., Ross, R., Lavie, C., Wisloff, U., Stensvold, D., \& Kaminsky, L. (2019). Development of global reference standards for directly measured cardiorespiratory fitness: A Report from the Fitness Registry and Importance of Exercise National Database (FRIEND). Mayo Clinic Proceedings, 95. https://doi.org/10.1016/j.mayocp.2019.06.013

Podrigalo, L.V., Artemieva, H.P., Rovnaya, O.A., Misevra, N.S., Sotnikova-Meleshkina, Zh.V., Podavalenko, A.P., Sokol, K.M., \& Robak, I.Yu. (2019). Features of physical development and somatotype of girls and women involved in fitness. Pedagogics, psychology, medical-biological problems of physical training and sports, 23, 189-195. https://doi.org/10.15561/18189172.2019.0405

Rzepko, M., Drozd, S., Żegleń, P., Król, P., Bajorek, W., \& Czarny, W. (2019). The Effect of training experience on postural control in competitive wrestlers. Journal of Human Kinetics, 70(1), 39-45. https://doi.org/10.2478/hukin-2019-0048

Song, Ch., Ikei, H., Kagawa, T., \& Miyazaki, Y. (2019). Effects of walking in a forest on young women. International Journal of Environmental Research and Public Health, (16), 229. https://doi.org/10.3390/ijerph16020229

Tavares, J., Biasotto-Gonzalez, D. Boa Sorte S. Suzuki, F. Lucareli, P., \& Politti, F. (2019) Related Changes in Postural Control in Physically Inactive Older Women. Journal of Geriatric Physical Therapy, 42(3), E81-E86. https://doi.org/10.1519/JPT.0000000000000169

Truszczynska-Baszak, A., Jarmuziewicz, A., \& Drzał-Grabiec, J. (2015). Effect of participating in fitness classes on postural stability of young women. Biomedical Human Kinetics, 7(1), 29-33. https://doi.org/10.1515/bhk-2015-0005

Vysotskaya, T., Shutova, T., \& Golubnichy, S. (2020). The effective means of aquafitness in correction of mature women's functional state. Journal of Human Sport and Exercise, 15(2proc), 189-199. https://doi.org/10.14198/jhse.2020.15.Proc2.09

Yarmak, O., Buhaienko, T., Zhukov, O., Cherniakova, Z., Vorona, V., Bilenkova, L., \& Blagii, O. (2019). Specificity of the relationship between the volume of physical activity and the physical condition of 18-19-year-old girls. Journal of Physical Education and Sport, 19(3), 1550-1555. https://doi.org/10.7752/jpes.2019.03224

Yarmak, O., Blagii, O., Palichuk, Y., Hakman, A., Balatska, L., Moroz, O., \& Galan, Y. (2018). Analysis of the factor 
Andrieieva, O., Yarmak, O., Kashuba, V., Drozdovska, S., Gineviciene, V., Blagii, O., \& Akimova-Ternovska, M. (2020). Efficiency of a Combined Fitness Program for Improving Physical Condition in Young Women

structure of the physical condition of girls 17-19 year old. Journal of Human Sport and Exercise, 13(2proc), 259-268. https://doi.org/10.14198/jhse.2018.13.Proc2.1

Yelizarova, O., Stankevych, T., Parats, A., Antomonov, M., Polka, N., \& Hozak, S. (2020). Specific features of the Ukrainian urban adolescents' physical activity: A crosssectional study. Journal of Environmental and Public
Health, Art. ID 3404285.

https://doi.org/10.1155/2020/3404285

Yuriev, Yu. (1991). Motor tests in foreign countries. Fizicheskaya kultura $v$ shkole, 6, 53-54.

Zhygalova, Ya.V., \& Tarasova, L.V. (2003). Designing integrated health-enhancing fitness-programs for 30-50 year-old women. Teoriya i praktika fizicheskoy kultury, (6), 56-57.

\title{
ЕФЕКТИВНІСТЬ КОМПЛЕКСНОЇ ФІТНЕС-ПРОГРАМИ У ПІДВИЩЕННІ РІВНЯ ФІЗИЧНОГО СТАНУ МОЛОДИХ ЖІНОК
}

\author{
Олена Андрєєва ${ }^{1 \mathrm{ABCD}}$, Олена Ярмак ${ }^{2 \mathrm{ABCD}}$, Віталій Кашуба $^{1 \mathrm{ABCD}}$, Світлана Дроздовська ${ }^{1 \mathrm{ABCD}}$, \\ Валентина Гіневічєне ${ }^{3 \mathrm{ABCD}}$, Олександра Благій ${ }^{1 \mathrm{ABCD}}$, Марія Акімова-Терновська ${ }^{1 \mathrm{ABCD}}$
}

\author{
${ }^{1}$ Національний університет фізичного виховання і спорту України \\ ${ }^{2}$ Білоцерковський національний аграрний університет \\ ${ }^{3}$ Вільнюський університет \\ Авторський вклад: А - дизайн дослідження; В - збір даних; C - статаналіз; D - підготовка рукопису; Е - збір коштів \\ Реферат. Стаття: 10 с., 8 табл., 41 джерел.
}

Метою даного дослідження було оцінити ефективність комплексної програми вправ, спрямованої на поліпшення фізичного стану молодих жінок.

Матеріали та методи. У дослідженні взяли участь 62 здорові жінки (середній вік 29,4 роки). Методологія дослідження включала оцінку більше 50 показників (антропометричні показники, фізичні і рухові якості, функціональний стан серцево-судинної і дихальної систем і т. д.). Аналіз даних проводили з використанням таких методів статистики: описові статистики, дисперсійний і факторний аналіз. Структуру фізичного стану жінок визначали за допомогою факторного аналізу.

Результати. Показники фізичного розвитку мали найбільший внесок $(33,4 \%)$ в загальну дисперсію характеристик фізичного стану учасників дослідження. Другий фактор, пов'язаний з функціональним станом і показниками фізичного стану, склав 21,6\%, третій фактор, пов'язаний 3 координаційними здібностями, склав 19,8\%, а четвертий фактор, пов'язаний $з$ фізичною підготовкою, склав 10,3\% від загальної дисперсії. Ці чотири фактори в сумі пояснювали 85,1\% загальної дисперсії. 35 показників, відібраних за допомогою факторного аналізу і характеризують фізичний стан жінок, використовували в якості критеріїв ефективності запропонованої фітнес-програми. Участь у фітнеспрограмі істотно вплинула на морфологічний статус жі- нок. Маса тіла знизилася на 5,6\% (р < 0,05), індекс Кетле зменшився на $11,2 \%(\mathrm{p}<0,05)$, а також зменшилися обхватні розміри: відношення довжини тіла до обхвату талії на $14,8 \%$ ( $<0,05)$, відношення довжини тіла до обхвату живота на 5,3\% (p < 0,05) і відношення довжини тіла до обхвату стегон на $6,7 \%(\mathrm{p}<0,05)$. Відзначено істотне поліпшення функціональних показників серцево-судинної системи, в тому числі ЧСС в спокої, яка знизилася на 16,2\% (p < 0,05). Час затримки дихання після вдиху (тест Штанге) і після видиху (тест Генчі) збільшився на 44,0 \% - 53,7\% (p < 0,05). Позитивні статистично значущі зміни $(\mathrm{p}<0,05)$ спостерігалися в показниках фізичної підготовленості жінок. М'язова сила збільшилася на 32,3\% ( $<0,05)$, швидкісна і силова витривалість і швидкісна витривалість збільшилися на $31,5 \%$ і 49,1\% відповідно ( $<$ 0,05). Використання спеціальних вправ для розвитку координаційних здібностей позитивно вплинуло на функцію рівноваги, проба Ромберга покращилася на 94,0\% при р < 0,05, а тест «Фламінго» на 65,6\% при $\mathrm{p}<0,05$.

Висновки. Оцінка ефективності комплексної фітнеспрограми виявила достовірні позитивні довгострокові ефекти впливу на рівні фізичного стану, морфологічного статусу, стану здоров'я і загального самопочуття молодих жінок.

Ключові слова: програма, фітнес-тренування, фізичний стан, молоді жінки 


\section{Information about the authors:}

Andrieieva Olena: olena.andreeva@gmail.com; http://orcid.org/0000-0002-2893-1224; Department biomechanics and sport metrology, National University of Ukraine on Physical Education and Sport, Fizkultury St, 1, Kyiv, 03150, Ukraine.

Yarmak Olena: yarmak_en@ukr.net; http://orcid.org/0000-0002-6580-6123; Bila Tserkva National Agrarian University, Soborna Pl, 8/1, Bila Tserkva, Kyivska oblast, 09117, Ukraine.

Kashuba Vitalii: kashubavo@gmail.com; https://orcid.org/0000-0001-6669-738X; Department biomechanics and sport metrology, National University of Ukraine on Physical Education and Sport, Fizkultury St, 1, Kyiv, 03150, Ukraine.

Drozdovska Svitlana: sdrozdovska@gmail.com; https://orcid.org/0000-0002-6211-5204; Department biomechanics and sport metrology, National University of Ukraine on Physical Education and Sport, Fizkultury St, 1, Kyiv, 03150, Ukraine.

Gineviciene Valentina: valentina.gineviciene@gmail.com; https://orcid.org/0000-0003-4956-6307; Department of Human and Medical Genetics Institute of biomedical science Faculty of Medicine, Vilnius University, Santariskiu St, 2, LT-08661 Vilnius, Lithuania.

Blagii Oleksandra: blagiy.s@gmail.com; https://orcid.org/0000-0001-8923-7319; Department biomechanics and sport metrology, National University of Ukraine on Physical Education and Sport, Fizkultury St, 1, Kyiv, 03150, Ukraine.

Akimova-Ternovska Maria: akimova@gmail.com; https://orcid.org/0000-0003-3974-2266; Department biomechanics and sport metrology, National University of Ukraine on Physical Education and Sport, Fizkultury St, 1, Kyiv, 03150, Ukraine.

Cite this article as: Andrieieva, O., Yarmak, O., Kashuba, V., Drozdovska, S., Gineviciene, V., Blagii, O., \& Akimova-Ternovska, M. (2020). Efficiency of a Combined Fitness Program for Improving Physical Condition in Young Women. Teoriâ ta Metodika Fizičnogo Vihovannâ, 20(4), 195-204. https://doi.org/10.17309/tmfv.2020.4.01

Received: 15.06.2020. Accepted: 20.12.2020. Published: 25.12.2020

This work is licensed under a Creative Commons Attribution 4.0 International License (http://creativecommons.org/licenses/by/4.0). 